\title{
Distribution of Alkaline Phosphatase-Hydrolyzable Phosphorus in 15 Lakes in Japan
}

\author{
Masako Tabata, Naomi Tsunekı, Mikio Ishi, Junzo Suzuki and \\ Shizuo SUZukI
}

\begin{abstract}
Distribution of total phosphorus (T-P), orthophosphate (Ort-P) and alkaline phosphatase-hydrolyzable phosphorus (ALP-P) were examined in the water of 15 lakes. The ratio of Ort-P to $\mathrm{T}-\mathrm{P}$ was low in most lakes studied. A considerable proportion of soluble organic phosphorus (62\% on average) was ALP-P. The sum of Ort-P and ALP-P, which was thought to be utilized by plankton in lake water, readily accounted for $71 \%$ of total soluble phosphorus.

Gel chromatography analyses (Sephacryl S-200) revealed that two fractions of phosphorus compounds (high and low molecular weight) existed in the water of $\mathrm{L}$. Inbanuma and L. Kawaguchiko. A portion of the high molecular weight phosphorus of each sample was hydrolyzed by alkaline phosphatase, which indicated that it was composed of a phosphomonoester bound to a high molecular substance such as humic acid.
\end{abstract}

Key words : lake, alkaline phosphatase-hydrolyzable phosphorus, total phosphorus, orthophosphate

\section{Introduction}

Phosphorus has been found to be the most important factor in regulating primary production by phytoplankton and its standing crop in natural water. Various forms of phosphorus, in addition to orthophosphate, are present in natural waters (Hooper, 1973). Attempts have been made to classify phosphorus in water (Tакімото et al., 1979 ; 1981). A phosphatase-hydrolyzable phosphorous compound has also been found in natural water (Herbes et al., 1975; Francko and Неath, 1979 ; Chrost et al., 1988).

Phosphatase activity of lake or sea waters has been determined, and the role of the enzyme in mineralization of dissolved organic phosphorus in the water has been assessed (BERMAN, 1970 ; KoBORI and TAGA, 1979 ; MAEDA, 1988).

It has thus been concluded that phosphatasehydrolyzable phosphorus is significant as a bioavailable phosphorus in natural water in addition to orthophosphate. Distribution of and variation in alkaline phosphatase-hydrolyzable phosphorus (ALP-P) in lakes, however, has not been thoroughly studied. The present study was carried out to analyse the distribution of ALP-P concentrations and their correlation with chlorophyll a in 15 lakes in Japan.

\section{Materials and methods}

\section{2-1. Samples}

Water samples were collected from the surface layer of the 15 lakes listed in Table 3 from May to September, 1987. Samples were brought back to the laboratory, kept at $4^{\circ} \mathrm{C}$ and analysed as soon as possible.

\section{2-2. Chemical analyses}

Lake water was filtrated using a membrane filter (TOYO, $0.45 \mu \mathrm{m}$ ). Total phosphorus (T-P) and ALP-P concentrations of whole lake water as well as the filtrate (soluble total phosphorus ; Solb. T-P, soluble ALP-P; Solb. ALP-P) and orthophosphate (Ort-P) of the filtrate were measured according to the following method: 
Suspended total phosphorus (Susp. T-P) concentration was obtained by subtracting Solb. T -P from T-P. Suspended ALP-P (Susp. ALP $-P)$ was estimated by subtracting Solb. ALP-P from ALP-P.

Ort $-\mathrm{P}$ and $\mathrm{T}-\mathrm{P}$ were measured by the molybdenum-blue method (Pharmaceutical Society JAPAN, 1980). ALP-P was measured as follows: $100 \mathrm{ml}$ of sample containing $9 \mathrm{ml}$ of $0.15 \mathrm{M}$ Tris $-\mathrm{HCl}$ buffer $(\mathrm{pH} 10.0)$ and $1 \mathrm{ml}$ of alkaline phosphatase solution (Sigma Type I, $0.67 \mathrm{mg} \cdot \mathrm{ml}^{-1}$ Tris- $\mathrm{HCl}$ buffer solution) was mixed and incubated at $37^{\circ} \mathrm{C}$. After 1 hour and again after 2 hours, Ort-P concentrations of a portion of the mixture were measured as described above.

2-3. Alkaline phosphatase activity and bacterial number determination

Alkaline phosphatase activity was measured by the fluorometric method using 4-methylumbelliferyl phosphate as a substrate after $\mathrm{H}_{\mathrm{A}}$. SHIMOTо et al. (1983).

Phosphatase producing bacteria in the lake water were counted by the most probable number method (Pharmaceutical. Society Japan, 1980) using a medium of $0.25 \mathrm{~g}$ peptone, $0.25 \mathrm{~g}$ yeast extract, $0.25 \mathrm{~g}$ phenolphthalein diphosphate sodium salt, and $0.01 \mathrm{~g} \mathrm{FeSO}_{4} \cdot 7 \mathrm{H}_{2} \mathrm{O}$ in $1000 \mathrm{ml}$ of water and adjusted to $\mathrm{pH} 7.6$. The diluted lake water was incubated in this medium for 5 days at $25^{\circ} \mathrm{C}$.

\section{2-4. Gel chromatography}

Filtrate of lake water (using a $0.45 \mu \mathrm{m}$ membrane filter) was concentrated by ultrafiltration (TOYO UH-1, fractionated molecular weight 1000). The concentrate was then applied to a gel column (Sephacryl S-200, Pharmacia). The sample was eluted with $0.2 \mathrm{M}$ borate buffer (pH8.6), and T-P concentration of each fraction $(5 \mathrm{ml})$ was measured by the method described above.

\section{Results and discussion}

In this experiment, alkaline phophatase from bovine intestine (EC. 3.1.3.1, Sigma Type I) was used to determine ALP-P concentration of lake waters. Table 1 shows the rate of activity of the alkaline phosphatase against several compounds as measured by the release of ortho-
Table 1. Activity of alkaline phosphatase against different compounds

\begin{tabular}{lc}
\hline \multicolumn{1}{c}{$\begin{array}{c}\text { Compound tested } \\
\text { as substrate }\end{array}$} & $\begin{array}{c}\text { Relative reaction } \\
\text { velocity (\%) }\end{array}$ \\
\hline$\beta$-glycerophosphate & 100 \\
ADP & 84 \\
Glucose-6 phosphate & 68 \\
ATP & 18 \\
Phosphocholine & 17 \\
Pyrophosphate & 1 \\
cyclic-AMP & 1 \\
DNA & 0 \\
Lecithin & 0 \\
Tripolyphosphate & 0 \\
Phytin & 0 \\
Phytic acid sodium salt & 0 \\
\hline
\end{tabular}

Each substrate was incubated with $0.67 \mathrm{mg}$ of Alkaline phosphatase (Sigma Type I) at $\mathrm{pH} 10$, $37^{\circ} \mathrm{C}, 1$ hour.

Ortho-phosphate of the mixture was measured by molybdenum blue method.

Table 2. Effect of orthophosphate on alkaline phosphatase activity.

\begin{tabular}{cc}
\hline $\begin{array}{c}\text { Orthophosphate } \\
\left(\mu \mathrm{g} \cdot 1^{-1}\right)\end{array}$ & $\begin{array}{c}\text { ALP activity } \\
(\%)\end{array}$ \\
\hline 0 & 100 \\
0.01 & 98 \\
0.1 & 95 \\
1 & 93 \\
10 & 55 \\
100 & 0 \\
\hline
\end{tabular}

phosphate. Activity was observed against all the phosphomonoesters tested, but the enzyme did not liberate orthophosphate from nucleic acid, phytin, tripolyphosphate or lecithin.

The effect of orthophosphate concentrations on the activity of the enzyme was examined (Table 2). The activity was inhibited by orthophosphate of over $1 \mu \mathrm{g} \cdot \mathrm{ml}^{-1}$. Since orthophosphate concentrations from lake water samples were below $1 \mu \mathrm{g} \cdot \mathrm{ml}^{-1}$, hydrolyzation of ALP$\mathrm{P}$ in lake water to orthophosphate by the enzyme would be thoroughly complete.

Orthophosphate liberation from mixtures of each sample and alkaline phosphatase was measured after 1 and 2 hour incubations. All the ALP-P of each sample was considered to 
Table 3. Distribution of phosphorous compounds, chlorophyll a and phosphatase-producing bacteria in lake water.

\begin{tabular}{|c|c|c|c|c|c|c|c|c|c|c|c|}
\hline \multirow[b]{2}{*}{ Lake } & \multirow[b]{2}{*}{ Date } & \multirow[b]{2}{*}{$\mathrm{pH}$} & \multirow[b]{2}{*}{ ALP } & \multirow[b]{2}{*}{ Chl-a } & \multirow{2}{*}{$\begin{array}{c}\text { Org }-\mathrm{P} \\
\text { bacteria }\end{array}$} & \multicolumn{6}{|c|}{ Phosphorous compounds } \\
\hline & & & & & & $\mathrm{T}-\mathrm{P}$ & $\begin{array}{l}\text { Susp. } \\
\mathrm{T}-\mathrm{P}\end{array}$ & $\begin{array}{r}\text { Susp. } \\
\text { ALP-P }\end{array}$ & $\begin{array}{r}\text { Solb. } \\
\mathrm{T}-\mathrm{P}\end{array}$ & $\begin{array}{r}\text { Solb. } \\
\text { ALP-P }\end{array}$ & Ort-P \\
\hline Teganuma & 10 June & 8.7 & 34.1 & 348.0 & - & 870 & 444 & 24 & 426 & 33 & 319 \\
\hline Ushigomebori & 5 June & 8.3 & 25.9 & 181.0 & 320 & 334 & 302 & 2 & 32 & 19 & 5 \\
\hline Koaidame & 15 July & 9.1 & 16.6 & 98.4 & 1100 & 270 & 250 & 15 & 20 & 8 & 9 \\
\hline Kitaura & 24 June & 9.3 & 35.3 & 89.7 & 930 & 134 & 99 & 10 & 35 & 13 & 4 \\
\hline Inbanuma & 10 June & 7.5 & 18.7 & 76.0 & - & 268 & 206 & 3 & 62 & 34 & 23 \\
\hline Beshonuma & 15 July & 8.4 & 58.3 & 74.5 & 17200 & 171 & 155 & 0 & 16 & 8 & 4 \\
\hline Shakujiiike & 15 July & 9.3 & 13.3 & 42.2 & 1700 & 117 & 96 & 7 & 21 & 17 & 2 \\
\hline Shinseiko & 3 July & 7.6 & 57.8 & 29.3 & 2400 & 43 & 28 & 0 & 15 & 10 & 2 \\
\hline Kasumigaura & 24 June & 8.5 & 17.9 & 19.5 & 9300 & 124 & 91 & 0 & 33 & 12 & 6 \\
\hline Akagi-Kono & 9 July & 6.3 & 309.9 & 14.7 & 790 & 31 & 23 & 2 & 8 & 4 & 4 \\
\hline Shojiko & $26 \mathrm{May}$ & 7.1 & 4.9 & 6.2 & - & 66 & 13 & 0 & 53 & 5 & 2 \\
\hline Nakanuma & 10 June & 7.3 & 8.5 & 5.2 & - & 26 & 7 & 5 & 19 & 6 & 4 \\
\hline Kawaguchiko & 26 May & 7.6 & 14.8 & 5.2 & - & 33 & 6 & 0 & 27 & 10 & 2 \\
\hline Akagi-Ono & 9 July & 8.2 & 10.5 & 2.0 & 110 & 16 & 8 & 0 & 8 & 5 & 2 \\
\hline Kakumanbuchi & 9 July & 6.4 & 16.6 & 1.8 & 7900 & 18 & 8 & 3 & 10 & 6 & 2 \\
\hline \multicolumn{12}{|c|}{$\begin{array}{l}\text { ALP-activity: alkaline phosphatase activity }\left(\mathrm{nmol} \cdot \min ^{-1} \cdot 1^{-1}\right) ; \text { Chl-a: Chlorophyll } a\left(\mu \mathrm{g} \cdot 1^{-1}\right) \text {; Org. } \\
\mathrm{P} \text { bacteria: number of phosphatase-producing bacteria }\left(\mathrm{N} \cdot \mathrm{ml}^{-1}\right) ; \mathrm{T}-\mathrm{P}: \text { total phosphorus }\left(\mu \mathrm{g} \cdot 1^{-1}\right) ; \text { Susp. } \\
\mathrm{T}-\mathrm{P} \text { : suspended total phosphorus }\left(\mu \mathrm{g} \cdot 1^{-1}\right) \text {; Susp. ALP-P: suspended phosphorus decomposed with alka- } \\
\text { line phosphatase }\left(\mu \mathrm{g} \cdot 1^{-1}\right) \text {; Solb. T-P: soluble total phosphorus }\left(\mu \mathrm{g} \cdot 1^{-1}\right) \text {; Solb. ALP-P: soluble } \\
\text { phosphorus decomposed with alkaline phosphatase }\left(\mu \mathrm{g} \cdot 1^{-1}\right) ; \text { Ort-P: orthophosphate }\left(\mu \mathrm{g} \cdot 1^{-1}\right) ;-: \text { not } \\
\text { determined. }\end{array}$} \\
\hline
\end{tabular}

decompose to orthophosphate after 1 hour incubation, since no increase in orthophosphate liberation was observed after 2 hours.

Table 3 shows the data of $\mathrm{pH}$, phosphorous compounds, activity of alkaline phosphatase and number of phosphatase producing bacteria in the water of 15 lakes. Chlorophyll a concentration was not in proportion to numbers of phosphatase producing bacteria. $\mathrm{pH}$ of lake waters was almost neutral or weakly alkaline. Phosphorous concentration in L. Teganuma was remarkably high. Suspended and soluble ALP-P values were $0-24$ and $4-34 \mu \mathrm{g} \cdot 1^{-1}$, respectively, and were slightly higher than those of sea and river water noted by CHRost et. al. (1986).

Table 4 shows the ratio of the various forms of phosphorus in samples. The ratio of Ort-P to $\mathrm{T}-\mathrm{P}$ was low (average $8.5 \%$ ). ALP-P accounted for $62 \%$ of soluble organic phosphorus. The greater proportion of Solb. T-P was concluded to be in phosphorus compounds which are readily utilized by plankton in natural water, since the sum of Ort $-\mathrm{P}$ and Solb. ALP-P accounted for $71 \%$ to Solb. T-P on average. ТАкімото $e t$ al. (1979) measured concentrations of phosphorus decomposed by $U V$ radiation as organic monophosphate in sea and river water, and also reported a high ratio of the organic monophosphate to $\mathrm{T}-\mathrm{P}$.

The correlation coefficients of chlorophyll $a$ and the various forms of phosphorus (except the data of L. Teganuma) are shown in Table 5. Chlorophyll $a$ correlated very well with total phosphate, but not with the others. A weak relationship was observed between chlorophyll $a$ and the sum of Solb. ALP-P and Susp. ALP$\mathrm{P}$, and between chlorophyll $a$ and the sum of Ort-P and Solb.ALP-P and Susp. ALP-P. The ratios of Ort-P to T-P and of Susp. ALP-P plus Solb.ALP-P to T-P have a tendency to be inversely proportional to chlorophyll $a$ con- 
Table 4. Ratio of various forms of phosphorous compounds in lake water.

\begin{tabular}{lcccc}
\hline \multicolumn{1}{c}{ Lake } & $\begin{array}{c}\text { Ort-P/T-P } \\
(\%)\end{array}$ & $\begin{array}{c}\text { Solb.T-P } \\
/ \text { T-P } \\
(\%)\end{array}$ & $\begin{array}{c}\text { Solb.ALP-P } \\
\text { /Solb. Org-P* } \\
(\%)\end{array}$ & $\begin{array}{c}\text { Ort - P + Solb. ALP-P } \\
\text { /Solb. T-P } \\
(\%)\end{array}$ \\
\hline Teganuma & 36.7 & 49.0 & 30.8 & 82.6 \\
Ushigomebori & 1.5 & 9.6 & 70.4 & 75.0 \\
Koaidame & 3.3 & 7.4 & 72.7 & 85.0 \\
Kitaura & 3.0 & 26.1 & 41.9 & 48.6 \\
Inbanuma & 8.6 & 23.1 & 87.2 & 91.9 \\
Beshonuma & 2.3 & 9.4 & 66.7 & 75.0 \\
Shakujiiike & 1.7 & 17.9 & 89.5 & 90.5 \\
Shinseiko & 4.7 & 34.9 & 76.9 & 80.0 \\
Kasumigaura & 4.8 & 26.6 & 44.4 & 100.0 \\
Akagi-Kono & 12.9 & 25.8 & 100.0 & 13.2 \\
Shojiko & 3.0 & 80.3 & 9.8 & 52.6 \\
Nakanuma & 15.4 & 73.1 & 40.0 & 44.4 \\
Kawaguchiko & 6.1 & 81.8 & 40.0 & 87.5 \\
Akagi-Ono & 12.5 & 50.0 & 83.3 & 80.0 \\
Kakumanbuchi & 11.1 & 55.6 & 75.0 & 70.7 \\
\hline Average & 8.5 & 38.0 & 61.9 & \\
\hline
\end{tabular}

$*$ Solb. Org $-\mathrm{P}=$ Solb. $\mathrm{T}-\mathrm{P}-$ Ort-P

Table 5. Correlation coefficients between various form of phosphorous compound and chlorophyll $a$.

\begin{tabular}{|c|c|}
\hline & Chlorophyll $a$ \\
\hline $\mathrm{T}-\mathrm{P}$ & $0.9122^{* * *}$ \\
\hline Solb. T-P & 0.2660 \\
\hline Ort-P & 0.3436 \\
\hline Solb.ALP-P & $0.5129^{*}$ \\
\hline Susp. ALP-P & 0.3745 \\
\hline $\begin{array}{l}\text { Ort }-\mathrm{P} \\
\quad+\text { Solb. ALP-P }\end{array}$ & $0.4675^{*}$ \\
\hline $\begin{array}{l}\text { Solb. ALP-P } \\
\quad+\text { Susp. ALP-P }\end{array}$ & $0.6102^{* *}$ \\
\hline $\begin{array}{l}\text { Ort-P } \\
\quad+\text { Solb. ALP-P } \\
\text { + Susp. ALP-P }\end{array}$ & $0.5431^{* *}$ \\
\hline Ort-P/T-P & $-0.5746^{* *}$ \\
\hline $\begin{array}{l}\text { Solb. ALP-P }+ \\
\text { Susp. ALP-P/T-P }\end{array}$ & $-0.5990^{* *}$ \\
\hline
\end{tabular}

tents. It is supposed that plankton immediately consumed Ort-P or ALP-P in the lake water, and then stored it in their bodies. Minear (1972) found that phytoplankton consume and release organic phosphorus simultaneously. After phytoplankton die, decomposition of the debris and release of orthophosphate occurs. Thus, the total amount of phosphorus and the decomposition rate of organo phosphorus to orthophosphate in the lake water are thought to be significant factors to regulating phytoplankton growth.

Alkaline phosphatase activity and phosphatase producing bacteria which participated in the decomposition of ALP-P were detected, but no correlation was found between the phosphatase activity and the concentrations of phosphorous compounds in the lakes. It has been reported that, under certain circumstances, some algae or bacteria release extracellular alkaline phosphatase when orthophosphate disappears (WYNNE, 1981). In this experiment, an inverse proportion between alkaline phosphatase activity and orthophosphate concentra tions in lake waters was not observed.

Gel filtration chromatography was conducted on filtrated water of $\mathrm{L}$. Inbanuma and $\mathrm{L}$. Kawaguchiko (Figure 1). On both chromatograms, two peaks of phosphorus were obser- 

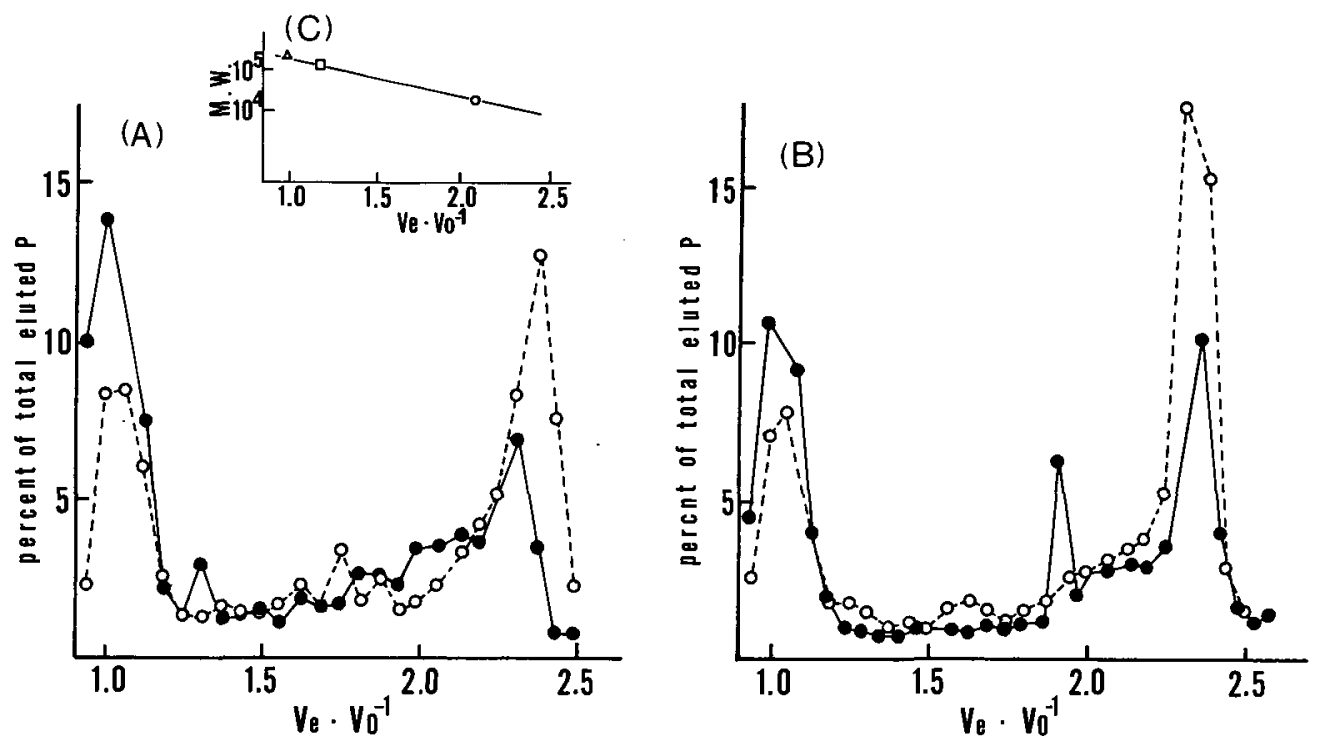

Fig. 1. Elution profile of phosphorous compound of (A) Inbanuma and (B) Kawaguchiko lake water on Sephacryl S-200.

-.. -.. ALP treated

$\longrightarrow$ ALP no treated

(C) Sephacryl S-200 calibration curve

$\triangle$ Blue dextran (molecular weight : 2,000,000)

$\square$ Alcohol dehydrogenase (molecular weight : 150,000)

Cytochrome C (molecular weight : 12,400)

Table 6. Elution rate of phosphorus compound on Sephacryl S-200.

\begin{tabular}{|c|c|c|c|c|c|}
\hline \multirow{3}{*}{ Sample } & \multicolumn{5}{|c|}{ phosphorus (\%) } \\
\hline & \multicolumn{3}{|c|}{$\begin{array}{l}\text { High molecular } \\
\text { fraction }^{1)}\end{array}$} & \multicolumn{2}{|c|}{$\begin{array}{c}\text { Low molecular } \\
\text { fraction }^{2}\end{array}$} \\
\hline & & $-\mathrm{ALP}$ & $+\mathrm{ALP}^{3)}$ & $-\mathrm{ALP}$ & $+\mathrm{ALP}^{3}$ \\
\hline Inbanuma & $r$ & 45 & 29 & 20 & 34 \\
\hline Kawaguchiko & & 31 & 24 & 18 & 33 \\
\hline
\end{tabular}

1) $V_{e} \cdot V_{0}{ }^{-1}=0.94-1.19$ on chromatogram of Sephacryl S-200 (Fig. 1)

2) $\mathrm{V}_{\mathrm{e}} \cdot \mathrm{V}_{0}{ }^{-1}=2.21-2.38$ on chromatogram of Sephacryl S-200 (Fig. 1)

3) Sample was treated with $0.67 \mathrm{mg}$ of $\mathrm{ALP}$ (Sigma Type I) at $\mathrm{pH} 1037^{\circ} \mathrm{C}$, 1hour.

ved: one at high molecular weight fraction $\left.\mathrm{Ve} \cdot \mathrm{Vo}^{-1}=0.94-1.19\right)$; and another at a low molecular weight fraction $\left(\mathrm{Ve} \cdot \mathrm{Vo}^{-1}=2.21-2\right.$. 38). Standard compounds such as Ort-P, adenosine-5'-monophosphate and DNA were eluted at $\mathrm{Ve} \cdot \mathrm{Vo}^{-1}=2.3,2.2,1.1$, respectively. After the samples were incubated with alkaline phosphatase (Sigma Type I), phosphorus concentration of high molecular weight fractions decreased and those of low molecular weight fractions increased in both samples. The rates of phosphorus in each fraction to total eluted phosphorus are shown in Table 6. Recovery rate of phosphorus eluted in each chromatography was $88-98 \%$. After alkaline phosphatase treatment, phosphorus of the high molecular weight fraction was thought to have been hydrolyzed to orthophosphate. In addition to Ort-P, phosphomonoesters hydrolyzed by alkaline phosphatase may also be present in the low molecular weight fraction. Nucleic acids such as DNA are presumed to be components of the 
high molecular weight fraction. Minear (1972) reported that the concentrations of soluble DNA ranged from 4 to $30 \mu \mathrm{g} \cdot 1^{-1}$ for the lake samples, and that $40-60 \%$ of the high-molecular weight $(>250,000)$ phosphorus was attributable to DNA. The alkaline phosphatase used in this experiment did not decompose DNA. ALP-P of the high molecular weight fraction may be composed of phosphomonoesters bound to a high molecular weight substance such as humic acid.

\section{摘 要}

\section{日本の 15 湖沼におけるアルカリホス ファターゼ分解性リン量の分布}

日本の富栄養化度の異なる 15 湖沿水の, 総リ ンオルトリンおよびアルカリホスファターゼ分 解性リン (ALP-P) 含量を評価した。総リンに対 するオルトリンの割合はいずれも低かった。溶存 している有機リンのうち, 平均 62\%は ALP-Pで あった。また植物プランクトンに利用され易いリ ンと考えられるオルトリンとALP-Pの総和量 は, 溶存の総りンの平均 71\%を占めていた。

印旛沼と河口湖水のリン化合物をゲルクロマト グラフィー (Sephacryl S-200)により分析したと ころ, 分子量 150,000 以上の高分子画分と 13,000 以下の低分子画分に分画された。高分子画分のリ ンの一部はアルカリホスファターゼで分解される が，それらはリン酸モノエステル類が，フミン酸 等のような高分子成分に付着したものであると考 えられた。

\section{References}

Berman, T. (1970) : Alkaline phosphatase and phos. phorus availability in Lake Kinneret. Limnol. Oceanogr., 15:663-674.

Chrost, R. J., W. Siuda, D. Albrecht, J. Overbeck (1986): A method for determining enzymatical. ly hydrolyzable phosphate (EHP) in natural waters. Limnol. Oceanogr., 31: 662-667.

Francko, D. A., R. T. Heath (1979) : Functionally distinct classes of complex phosphorus com. pounds in lake water. Limnol. Oceanogr., 24 : 463-473.

Hashimoto, S., K. Kobayashi, K. Fujiwara, H. Haragu. CHI and K. Fuwa (1983): Enzymatic activity determination of alkaline phosphatase dissolved in natural waters by fluorometry. Bunse- kikagaku, 32 : E177-184.

Herbes, S. E., H. E. Allen, K. H. Mancy (1975): Enzymatic characterization of soluble organic phosphorus in lake water. Science, 187: 432434.

Hooper, F. F. (1973): Origin and fate of organic phosphorus compounds in aquatic systems. Environmental phosphorus handbook (Wiley). pp. 179-199.

KoBori, H. and N. TAGA (1979): Phosphatase activity and its role in the mineralization of organic phosphorus in coastal sea water. J. Exp. Mar. Ecol., 36 : 23-39.

MAEDA, S. (1988) : Release of inorganic phosphorus by phosphatase in Lake Sagami. Jour. Water Waste, 30: 111-120.

MINEAR, R. A. (1972) : Characterization of naturally occuring dissolved organophosphorus com. pounds. Environ. Sci. Technol., $6: 431-437$.

Otsuki, A., M. Alzaki, T. Kawai (1987): Long-term variations of three types of phosphorus concentrations in highly eutrophic shallow lake Kasumigaura, with special reference to dissolved organic phosphorus. Jpn. J. Limnol., $48: \mathrm{S} 1-\mathrm{S} 11$.

Pharmaceutical Society OF Japan (1980): Standard method of analysis for hygienic chemists. Kanehara (in Japanese).

Takimoto, K., T. Mukai, M. Myojo, T. Kaneshige, M. Komuro (1979): Basic study on the chemical forms of dissolved phosphate in coastal maline. Japan J. Water Pollution Research, 2 : 237-243 (in Japanese).

Takimoto, K., T. Mukal, A. Ueno, M. Mrojo, N. Kaneshige (1981): Fluctuation of dissolved phosphate with some chemical forms in the season of blooming. Japan J. Water Pollution Research, 4 : 18-22. (in Japanese)

WYNNE, D. (1981): The role of phosphatases in the metabolism of Peridinium cincutum, from Lake Kinneret (Israel). Hydrobiologia, 83 : 9399.

（著者：田烟真佐子，常木尚美，石井美樹夫，鈴木 潤三, 鈴木静夫, 東京理科大学薬学部, $\boldsymbol{\top} 162$ 東京都 新宿区市々谷船河原町 12 ：Masako TABATA, Naomi Tsunekr, Mikio Ishit, Junzo Suzuki, Shizuo Suzuki, Faculty of Pharmaceutical Science, Science University of Tokyo, 12 Ichigaya Funagawara-machi, Shinjuku-ku, Tokyo 162)

Received : 14 July 1993

Accepted : 20 October 1.993 